\title{
Isozymic Identification of Zygotic Seedlings in Swingle Citrumelo Citrus paradisi $\times$ Poncirus trifoliata Nursery and Field Populations
}

\author{
Catalina M. Anderson ${ }^{1}$
}

Fruit Crops Department, IFAS, University of Florida, Gainesville, FL 32611

William S. Castle

Citrus Research and Education Center, IFAS, University of Florida, 700 Experiment Station Road, Lake Alfred, FL 33850

Gloria A. Moore ${ }^{2}$

Fruit Crops Department, IFAS, University of Florida, Gainesville, FL 32611

Additional index words. nucellar embryony, rootstock, roguing

\begin{abstract}
Isozyme analysis was the basis for determining the frequency of occurrence and the characteristics of zygotic plants in Swingle citrumelo seedling populations from various sources of open-pollinated seeds, in a commercial nursery of Swingle citrumelo before and after roguing, and in commercial orchards and rootstock trials where this rootstock was used. Most zygotic seedlings identified by isozyme analysis could be distinguished by careful examination of morphological characteristics. Frequencies of zygotic seedlings varied among seedling populations, but were in the range $(\approx 5 \%$ to $10 \%)$ found in previous studies. Roguing based primarily on size and growth habit of seedlings was effective in removing some, but not all, zygotic seedlings. Most of the remaining zygotic plants in the rogued population were found among the smaller seedlings. Trees budded on zygotic rootstock seedlings were found in two of the three groves studied, and in some instances an apparent incompatibility was developing in young trees.
\end{abstract}

The production of citrus nursery trees involves budding a scion cultivar onto a seedling rootstock. Citrus seeds can be used to clonally propagate rootstock because most embryos develop through nucellar embryony, a form of apomixis that produces embryos with the maternal genotype. Such seeds are polyembryonic and may or may not contain a viable zygotic embryo. The frequency of zygotic seedlings in citrus rootstock populations depends on both the cultivar and environmental conditions (Khan and Roose, 1988; Moore and Castle, 1988; Xiang and Roose, 1988).

Zygotic seedlings are generally considered undesirable as rootstock plants and efforts are made to remove them in the nursery before budding. This roguing process is based on the classic work of Webber (1932), who demonstrated that nursery tree uniformity was improved by removing off-type (presumably zygotic) seedlings. The horticultural advantages obtained from roguing in the nursery carried over to the orchard.

Webber relied on visual observation to identify off-type plants because no other method was available. Thus, he was unable to determine with certainty the origin of the plants he discarded or to determine if any zygotic seedlings remained after roguing. Visual selection is still the basis for roguing as currently practiced in commercial nurseries, and the proportion of unrogued zygotic seedlings is unknown. However, it is now possible to reliably separate zygotic and nucellar citrus plants by the use of isozyme analysis (Khan and Roose, 1988; Moore and Castle, 1988; Roose and Traugh, 1988; Torres et al., 1978, 1982; Xiang

Received for publication 8 Jan. 1990. Fla. Agr. Expt. Sta. J. Series no. R00387. We appreciate the assistance of Dan Milam in providing plants and allowing us to conduct part of these studies in his nursery. The cost of publishing this paper was defrayed in part by the payment of page charges. Under postal regulations, this paper therefore must be hereby marked advertisement solely to indicate this fact.

'Present address: INTA, Estacion Experimental Agropecuaria Concordia, CC 34 3200-Concordia, Entre Rios, Republics Argentina.

${ }^{2}$ To whom reprint requests should be addressed. and Roose, 1988). Therefore, we wished to determine if all zygotic seedlings in a population could be identified morphologically and whether such seedlings were being rogued before budding and planting in commercial groves.

Our objectives in this study were to determine, through the use of isozyme analysis, the frequency and characteristics of Swingle citrumelo zygotic plants: 1) in seedling populations from various sources of open-pollinated seeds; 2) in a commercial nursery before and after roguing; and 3) used as rootstock in commercial orchards and in rootstock trials. Swingle citrumelo [Citrus paradisi Macf. $\times$ Poncirus trifoliata (L.) Raf.] was chosen because it is rapidly becoming a popular rootstock in Florida (Castle et al., 1988). Also, prior studies showed that the frequency of zygotic plants in Swingle seedling populations may be as high as 18\% (Hutchison, 1974; Moore and Castle, 1988; Xiang and Roose, 1988).

\section{Materials and Methods}

Seed sources. Open-pollinated Swingle citrumelo seeds from seedling trees growing in three sites in Florida were evaluated. These included: a tree growing at the Univ. of Florida, Gainesville; a group of trees at the U.S. Dept. of Agriculture/Whitmore Foundation Farm, Leesburg; and 12-year-old trees that are part of a rootstock trial located in Indiantown. All of these seed source trees were screened isozymically and determined to be nucellar.

Mature fruits were collected from the tree at Gainesville and individual trees at Indiantown. The Indiantown site used in this study was a rootstock trial where 'Valencia' sweet orange [Citrus sinensis (L.) Osb.] trees budded onto 12 different rootstock cultivars were being evaluated. This trial included three rows of rootstock seedling trees that were the same rootstock used for the budded 'Valencia' trees. At this trial, seeds were taken from 11 individual Swingle citrumelo trees. The sampling method maximized the possibility for any zygotic seedling found in the population to have arisen via cross-pollination. Samples were 
collected from trees and positions on trees adjacent to the maximum number of different possible pollen sources. Seed from the U.S. Dept. of Agriculture Foundation Farm was bulked before receipt.

Seeds were extracted, washed, dried, treated with fungicide, and stored at $4 \mathrm{C}$ until they were sown (120 seeds from each tree or source) in flats in a greenhouse. Two to 4 months after germination, the number of seedlings produced per seed and the relative size of the seedlings (smallest, intermediate, and largest) were recorded. Leaf tissue was then collected for isozyme analysis.

Nursery seedlings. Swingle citrumelo seedlings growing in a central Florida commercial greenhouse nursery were analyzed before and after roguing. Before any roguing by the nurseryman, four trays (128 cells per tray) from among many trays were selected at random for isozyme analysis of each plant. The trays were sown with one seed per cell $\approx 3$ months before analysis. The number and relative size of seedlings per seed were recorded. Young leaves were collected and used immediately or stored in plastic bags at $4 \mathrm{C}$ until analyzed. Samples were used within 15 days of collection. A total of 602 seedlings was analyzed. Plants found to be zygotic, along with a like number of nucellar seedlings, were planted in larger pots and grown for 8 months after which the variation in leaf morphology was recorded and plant height was measured.

Seedlings remaining in the nursery were visually rogued by the nurseryman when they were $\approx 4$ months old. The plants that were not discarded were transplanted and divided into populations of relatively large and small seedlings. Leaf samples for isozyme analysis were taken from a block of 350 plants chosen at random from each population when the seedlings were $\approx 6$ months old. Later, 31 additional off-type plants from the large seedling class and 25 off-type plants from the small seedling class were visually selected and sampled.

Field trees. Budded trees on Swingle citrumelo in three commercial groves and three rootstock trials were sampled. Within a grove or trial, all of the sampled plants were the same age. Bark samples $\left(0.3 \mathrm{~cm}^{2}\right)$ were cut from the rootstock $\approx 2$ to 4 $\mathrm{cm}$ below the bud union and immediately placed in a plastic bag in an ice chest.

Electrophoretic analysis. Leaf sap was extracted by laying a filter paper wick (Whatman no. $3,3 \times 5 \mathrm{~mm}$ ) on the abaxial leaf surface and pressing it with a pestle until the wick was wet. When bark samples were analyzed, an extraction buffer of 0.05 M sodium phosphate, $\mathrm{pH} 7.0$, was used. The bark sample was dipped in the buffer and then squeezed against a filter paper wick with hand-held pliers.

Isozymes were separated on $19.5-\mathrm{cm}^{2}$ gels containing $8.3 \%$ Connaught starch (Fisher Scientific, Orlando, Fla.). Malate dehydrogenase (EC 1.1.1.37; $\mathrm{MDH}$ ), phosphoglucomutase (EC 2.7.5.1; PGM), and phosphohexose isomerase (EC 5.3.1.9; PHI) were resolved with the $\mathrm{pH} 5.7$ histidine-citrate $(\mathrm{H})$ buffer of Cardy et al. (1981). Electrophoresis was carried out at $4 \mathrm{C}$ for $5 \mathrm{hr}$ at 350 to $400 \mathrm{~V}$. For separation of glutamate oxaloacetate transaminase (EC 2.6.1.1; GOT) and shikimate dehydrogenase (EC 1.1.1.25; SkDH) isozymes, a Tris-borate-EDTA buffer system (K) of Loukas and Pontikis (1979) was used. Gels were run for 3 to $4 \mathrm{hr}$ at $250 \mathrm{~V}$. The solutions used for enzyme activity staining were as given by or slightly modified from Vallejos (1983).

Chi-square analysis was used to compare the frequency distributions of zygotic and nucellar seedlings in the populations. Differences in plant height between zygotic and nucellar seed- lings were tested using Wilcoxon's two-sample test (Sokal and Rohlf, 1981).

Rationale used in isozyme analysis. Isozymes have been used previously as genetic markers for distinguishing nucellar from zygotic seedlings in Citrus (Khan and Roose, 1988; Moore and Castle, 1988; Roose and Traugh, 1988; Torres et al., 1982; Xiang and Roose, 1988). Through the analysis of banding patterns, plants heterozygous and homozygous at a locus can be differentiated. Nucellar seedlings should have the same isozyme alleles as the seed parent. Variation at a locus coding for an enzyme indicates that the plant originated by sexual reproduction.

One could expect to identify a zygotic seedling arising from self-pollination $50 \%$ of the time through the examination of one heterozygous isozyme locus; $50 \%$ of the time the isozyme phenotype would be identical to that of the seed parent, in this case Swingle citrumelo (Moore and Castle, 1988; Torres et al., 1982). If five heterozygous and unlinked loci were-examined, it should be possible to identify $97 \%$ of the zygotic seedlings. The addition of one more such locus would raise the probability of identifying zygotic seedlings to $98 \%$. The statistical probabilities of detecting zygotic seedlings arising from outcrossing are not easily calculated because of the many potential pollen parents and their varying isozyme genotypes. Nevertheless, the probability should be high if a relatively large number of loci are examined.

Seven isozyme loci were examined in this study; Swingle citrumelo is heterozygous at each of these, producing three bands at dimeric enzyme loci (Got $-1, M d h-1, M d h-2$, and $P h i$ ) and two bands at monomeric enzyme loci (Pgm -1, Pgm -2, and Skdh) (Moore and Castle, 1988; Torres et al., 1978, 1982; unpublished data). Got -1 and $M d h-1$ are linked (Torres et al., 1985). The isozyme genotypes of Swingle were designated MS (Got1), FS (Mdh -1), FS (Mdh -2), FS (Phi), MS (Pgm -1), MS (Pgm2), and FS (Skdh) (Moore and Castle, 1988). All seed sources were analyzed at five unlinked loci $(M d h-1, M d h-2, P g m-1$, $P g m-2$, and $P h i$ ) with the $\mathrm{H}$ buffer system, The seedlings from the unrogued nursery population were examined for their isozyme phenotypes at all seven loci with $\mathrm{H}$ and $\mathrm{K}$ buffer systems. Gels run in $\mathrm{K}$ buffer revealed variability not detected at the loci examined using the $\mathrm{H}$ system in only one instance. Therefore, seedlings from the rogued nursery populations were analyzed at five loci and the additional two loci were used to verify questionable cases.

All bark samples from field trees were analyzed for all seven loci. Banding patterns for all enzyme systems, with the exception of MDH, were identical in nucellar leaf and bark samples. Swingle citrumelo bark samples showed unclear or missing bands for $M d h-2$, but $M d h-1$ behaved as in leaf samples.

\section{Results and Discussion}

Seed sources. The frequency of Swingle citrumelo zygotic seedlings varied from $1.2 \%$ (Gainesville) to $5.2 \%$ (Indiantown) among the total of 1085 plants grown from the three seed sources. These frequencies of zygotics are low compared with those reported earlier in Swingle populations (Hutchison, 1974; Moore and Castle, 1988; Xiang and Roose, 1988). However, the variation in frequency of zygotic seedlings among seed sources was not unexpected because previous research had shown that variation occurred in the production of zygotic seedlings in various lots (Moore and Castle, 1988) and in seed taken from the same tree in different years (Khan and Roose, 1988). The frequencies of zygotic seedlings in the samples from the individual trees at 
Indiantown ranged from $0 \%$ to $27 \%$. All of the sampled seedlings with variant isozyme phenotypes, with one exception, displayed only one or the other of the parental Swingle citrumelo alleles at an isozyme locus, i.e., were homozygous at the locus, and thus were likely to be zygotic seedlings that arose via selfing. One seedling showed an unclear banding pattern at one locus and may have arisen via outcrossing.

The absence of any seedlings arising from cross-pollination within the Indiantown population could be the result of differences in time of flowering among the various cultivars in the trial. However, this was not true for all the adjacent rootstock types. Also, all zygotic seedlings detected in samples from the other two locations produced banding patterns indicating homozygosity for a parental allele at one or more loci and showed no evidence of outcrossing. Furthermore, in other research, almost all detected zygotic seedlings in seedling populations of Swingle and other rootstock cultivars arose via selfing (Khan and Roose, 1988; Moore and Castle, 1988; Xiang and Roose, 1988). Thus, most Swingle citrumelo zygotic seedlings apparently arise via selfing.

Nursery seedlings. The germination percentage ranged from $83 \%$ to $91 \%$ among the four flats of unrogued Swingle citrumelo seedlings sampled from a commercial nursery. There were 5.3\% to $13.3 \%$ zygotic seedlings in individual flats, with a mean frequency of $9.3 \%$ in the total population of 602 plants (Table 1). These values are generally higher than those we obtained with the three seed sources and are more similar to those obtained in earlier studies (Hutchison, 1974; Moore and Castle, 1988; Xiang and Roose, 1988).

The zygotic seedlings identified in the unrogued nursery population, along with some nucellar seedlings, were transplanted to larger containers and observed for 8 months. At the end of this period, the zygotic seedlings were more variable and significantly shorter, with a mean height of $23.1 \mathrm{~cm}$ as compared to $42.2 \mathrm{~cm}$ for the nucellar plants (Wilcoxon's two-sample test, $P=0.0001)$. After transplanting, $8.9 \%$ of the zygotic seedlings died while all of the nucellar seedlings survived. The lower vigor of the zygotic seedlings, which all arose via selfing, may be an expression of inbreedirrg depression. Khan and Roose (1988) found that zygotic seedlings of Poncirus trifoliata also tended to be smaller than nucellar seedlings.

While transplanting and roguing, the nurseryman graded the seedlings into two size groups. He eliminated almost all of the zygotic plants from the sampled group of larger seedlings, but the frequency of zygotics $(3.7 \%)$ was significantly greater in the sampled group of smaller seedlings $\left(\chi^{2}=8.24, P<0.005\right.$; Table 1). The inability of the nurseryman to remove all of the

Table 1. Zygotic and nucellar plants identified by isozyme analysis in samples taken before and after roguing from a commercial nursery Swingle citrumelo seedling population.

\begin{tabular}{|c|c|c|c|c|c|}
\hline \multirow{3}{*}{$\begin{array}{l}\text { Time of } \\
\text { sampling }\end{array}$} & \multicolumn{4}{|c|}{ Type of plant } & \multirow[b]{3}{*}{ Total } \\
\hline & \multicolumn{2}{|c|}{ Zygotic } & \multicolumn{2}{|c|}{ Nucellar } & \\
\hline & No. & $\%$ & No. & $\%$ & \\
\hline Before roguing ${ }^{2}$ & 56 & 9.3 & 546 & 90.7 & 602 \\
\hline \multicolumn{6}{|l|}{ After roguing } \\
\hline Large $^{y}$ & 2 & 0.6 & 348 & 94.4 & 350 \\
\hline Smally & 13 & 3.7 & 337 & 96.3 & 350 \\
\hline Total & 15 & 2.1 & 685 & 97.9 & 700 \\
\hline
\end{tabular}

${ }^{z}$ Data for four flats.

y Arbitrary classification based on seedling height as judged by the cooperating nurseryman. zygotic seedlings, especially among the smaller plants, was partly the result of his roguing procedure. The nurseryman used as his main criteria for roguing such horticultural characteristics as height and root quality; thus, the generally shorter zygotics were concentrated in the population of smaller seedlings. Other morphological features more indicative of genetic origin were sometimes overlooked. Most zygotic seedlings at the time of roguing had a distinctive leaf morphology (Fig. 1), but in some cases the morphological variation was only detectable with close observation. Also, leaf and shoot morphological differences between zygotic and nucellar plants were more apparent in the larger seedlings.

Webber (1932) proposed that a population of citrus rootstock seedlings rogued of morphological variants, as well as exceptionally vigorous and weak plants, would be more uniform and composed primarily of nucellar seedlings. The difference in the frequency of zygotics between the groups of large and small seedlings in our study, plus the overall reduction in frequency of zygotics that resulted from roguing, supports Webber's proposal. Also, the objective determination of seedling origin by isozyme analysis confirms the usefulness of visual selection as a means to identify zygotics.

A second group of off-type plants was sampled from the general population of rogued seedlings, 31 from the large and 25 from the small seedling class, to obtain additional data regarding the usefulness of leaf morphology as a means of identifying zygotic plants. In seedlings from each of the large and small populations, $52 \%$ produced an isozyme pattern that varied from the nucellar genotype. We suspected the remaining seedlings that were morphologically but not isozymically variant to be tetraploids because of their thick, broad leaves and prominent oil glands (Barrett and Hutchison, 1978). Some may have been mutants, but these were most likely only a small percentage.

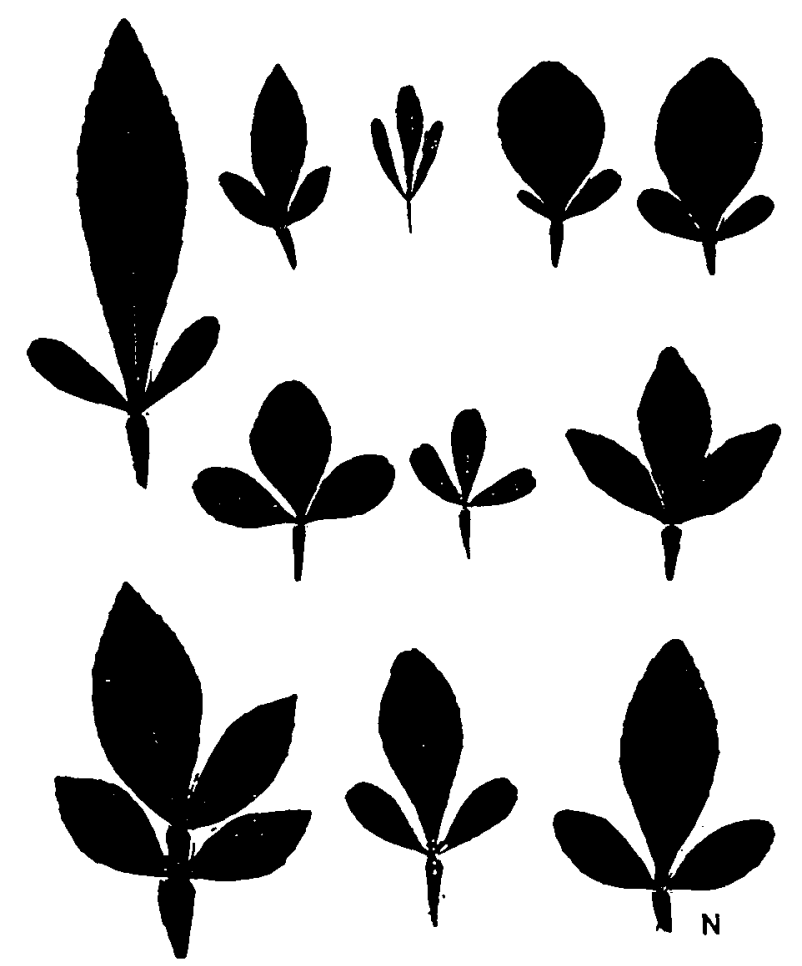

Fig. 1. Variation in leaf morphology among zygotic plants in a Swingle citrumelo seedling population in a commercial nursery. $\mathrm{N}=$ typical leaf morphology in a nucellar seedling.

J. Amer. Soc. Hort. Sci. 116(2):322-326. 1991. 
Some of the variation may have been epigenetic, i.e., not heritable. Isozyme analysis would not detect variants due to any of these causes. Finally, a few of these plants may have been zygotics that escaped detection on the basis of their isozyme banding patterns because the number of loci examined allowed detection of only $97 \%$ of the zygotic seedlings.

In the unrogued nursery population, more than one seedling frequently arose from a single seed; the mean number of plants produced per seed was 1.4 . When this occurred, the relative size of the seedlings was recorded as large, intermediate (if three seedlings were produced from a seed), and small (Table 2). When two seedlings were produced from a seed, the smaller of the two was more frequently zygotic in origin than the larger seedling. Likewise, in the 13 cases in which three seedlings were produced from a single seed, zygotic plants were found only among the smallest of the three seedlings. Therefore, the proportion of zygotic plants in a Swingle citrumelo seedling population could be reduced by roguing the smaller seedlings produced from individual seeds. However, zygotic plants were also relatively common $(13.4 \%)$ among seeds that produced only a single seedling.

Field trees. Overall, relatively few zygotic plants were detected in the commerical groves sampled, and these were confined to two groves (Table 3). In the navel orange grove, no zygotic plants were detected, but two isozymically variant (nontypical) plants were found. They were recognized by their isozyme banding patterns as Carrizo citrange rootstock. Twentyseven nontypical rootstock plants were found in one grove where 'Valencia' was the scion; seven were Swingle citrumelo zygotics and 20 were Carrizo citrange rootstock. The latter were probably replants. In the other 'Valencia' grove, 16 out of 307 plants had been propagated on zygotic seedlings (nine self-pollinated seedlings and seven possible outcrosses). An apparent incompatibility was developing on some of the trees with rootstock identified as Swingle citrumelo selfs. A strip of bark was

Table 2. Distribution of seedlings according to the number produced per seed in an unrogued Swingle citrumelo population of 602 plants derived from 448 seeds.

\begin{tabular}{|c|c|c|c|c|c|}
\hline \multirow{2}{*}{$\begin{array}{l}\text { Plants } \\
\text { produced } \\
\text { per seed } \\
\text { (no.) } \\
\end{array}$} & \multirow{2}{*}{$\begin{array}{c}\text { Seeds in } \\
\text { class } \\
\text { (no.) }\end{array}$} & \multirow{2}{*}{$\begin{array}{l}\text { Seedlings } \\
\text { produced } \\
\text { (no.) }\end{array}$} & \multirow{2}{*}{$\begin{array}{c}\text { Seedling } \\
\text { size and } \\
\text { no. }\end{array}$} & \multicolumn{2}{|c|}{$\begin{array}{l}\text { Zygotic } \\
\text { plants }\end{array}$} \\
\hline & & & & No. & $\%$ \\
\hline 1 & 307 & 307 & Large, 307 & 41 & 13.4 \\
\hline \multirow[t]{2}{*}{$?$} & 128 & 256 & Large, 128 & 2 & 1.6 \\
\hline & & & Small, 128 & 11 & 8.6 \\
\hline \multirow[t]{3}{*}{3} & 13 & 39 & Large, 13 & 0 & \\
\hline & & & Intermediate, 13 & 0 & \\
\hline & & & Small, 13 & 2 & 15.4 \\
\hline
\end{tabular}

${ }^{\mathrm{z}}$ As determined by isozyme analysis.

Table 3. Genotypes of rootstock plants in three commercial groves in Florida as determined by isozyme analysis.

\begin{tabular}{|c|c|c|c|c|c|c|}
\hline \multirow[b]{3}{*}{ Scion } & \multirow{3}{*}{$\begin{array}{c}\text { Trees } \\
\text { sampled } \\
\text { (no.) }\end{array}$} & \multicolumn{4}{|c|}{ Genotype } & \multirow{3}{*}{$\begin{array}{c}\text { Zygotic } \\
\text { plants } \\
(\%) \\
\end{array}$} \\
\hline & & \multicolumn{2}{|c|}{ Zygotic } & \multirow[b]{2}{*}{$\begin{array}{c}\text { Nucellar } \\
\text { (no.) }\end{array}$} & \multirow[b]{2}{*}{$\begin{array}{c}\text { Others } \\
\text { (no.) }\end{array}$} & \\
\hline & & $\begin{array}{c}\text { Selfed } \\
\text { (no.) }\end{array}$ & $\begin{array}{c}\text { Outcrossed } \\
\text { (no.) }\end{array}$ & & & \\
\hline Navel & 387 & 0 & 0 & 385 & $2^{z}$ & 0.0 \\
\hline Valencia & 307 & 9 & 7 & 290 & $1^{y}$ & 5.2 \\
\hline Valencia & 280 & 4 & 3 & 253 & $20^{z}$ & 2.5 \\
\hline
\end{tabular}

${ }^{z}$ Carrizo citrange.

`Sweet orange scion mistakenly sampled. removed across the bud union of a few of the 3-year-old trees in this grove that were found to be on zygotic rootstock. A bud union crease, similar to that reported with older trees (Rouse and Wutscher, 1985), was observed (Fig. 2). There were also differences in canopy size among the trees on the zygotic seedlings. Roose and Traugh (1988), in a more rigorous examination of trees propagated on zygotic seedlings in citrus rootstock trials, found similar effects. Some trees on zygotic rootstock were smaller and yielded less than trees on nucellar seedlings of the same cultivar while others were fairly similar or even superior to trees on nucellar seedlings. Roose and Traugh (1988) also reported that the smoothness of the bud union was affected by the genetic origin of the rootstock seedlings.

No zygotic plants were found in any of the three rootstock trials sampled in this research, where a total of 122 plants was tested. This result is meaningful because if the frequency of zygotics in trials is often lower than zygotic frequency in commercial plantings, and if trees on zygotic rootstock have poorer performance, then the commercial expectations for a particular rootstock might be somewhat less than predicted by data from rootstock trials.

Origin of zygotic seedlings. Typical gels stained for $\mathrm{MDH}$ and PHI are shown in Fig. 3. As stated above, all of the zygotic seedlings identified in the unrogued nursery population appeared to arise via selfing. In the rogued population, all of the zygotic seedlings arose via selfing with one exception. This seedling appeared to be derived via outcrossing, since alleles not carried by the maternal parent were expressed. The apparent frequen-
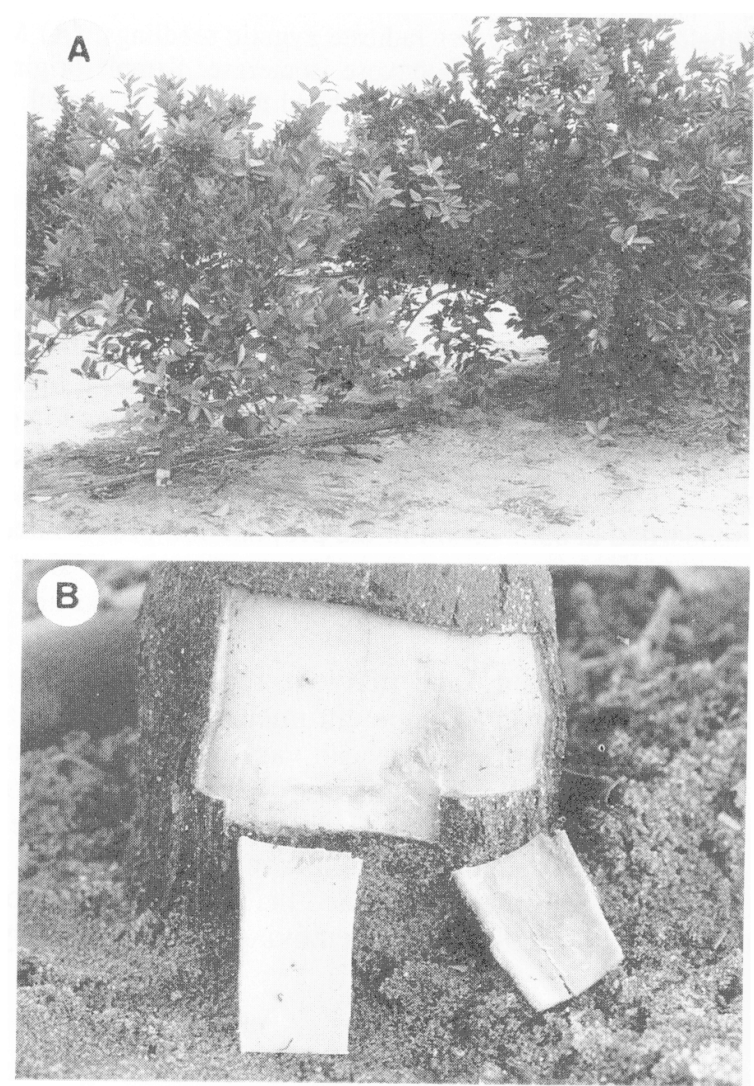

Fig. 2. (A) Three-year-old trees of 'Valencia' sweet orange propagated on a zygotic (left) and a nucellar (right) Swingle citrumelo rootstock seedling. (B) Trunk of the tree budded on the zygotic seedling showing an incipient bud union crease. 

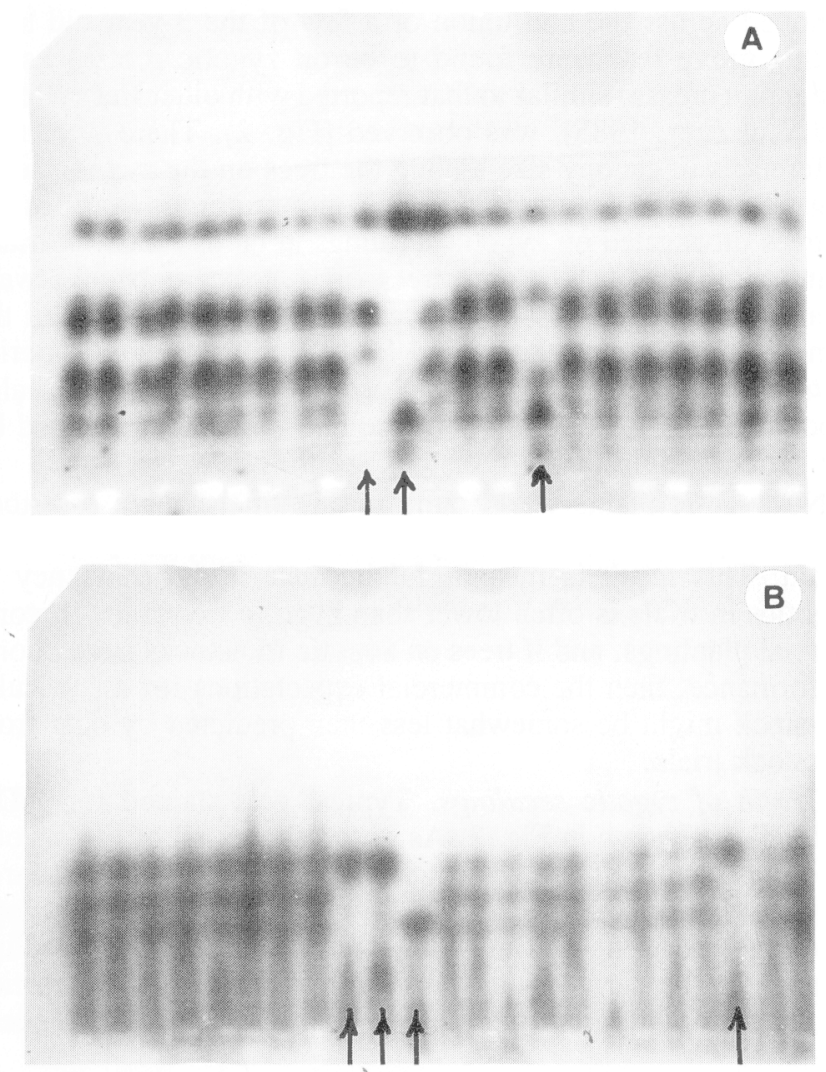

Fig. 3. Isozyme banding patterns of nucellar and zygotic Swingle citrumelo seedlings. Arrows indicate zygotic seedlings. (A) Malate dehydrogenase. (B) Phosphohexose isomerase. Sample origin is at the bottom of each photograph and band migration is anodal.

cies of outcrosses among zygotic rootstock seedlings in the two sampled 'Valencia' groves were $43.7 \%$ and $42.8 \%$. This result was unexpected since our and previous research suggest that most zygotic plants in rootstock seedling populations arise via self-pollination (Khan and Roose, 1988; Moore and Castle, 1988). However, Roose and Traugh (1988) also found that a high proportion of zygotic citrus rootstock seedlings originated via crosspollination in some rootstock trials examined. Many of the selfpollinated zygotic seedlings in rootstock populations may tend to be discarded at some point in the propagation process because of their inherently poor growth, whereas zygotics arising from cross-pollination may tend to be more vigorous and are more likely to be retained.

From both our study and previous reports, it is clear that zygotic plants occur in Swingle citrumelo seedling populations and that the number of zygotics can vary with the seed source. Our study, however, is different from previous ones involving isozymic analysis to determine seedling origin because we have shown that under commercial conditions some zygotics were not detected. We further determined that the probability of this occurring can be minimized by removing morphologically off- type seedlings and by discarding relatively small, weak-growing seedlings, especially the smaller ones among the two or three that arise from a single seed. Nonetheless, despite the roguing efforts of a skilled nurseryman and the opportunity to remove off-type and undesirable plants at several points in the propagation cycle, some nursery plants on zygotic rootstock will be planted. This occurrence was confirmed in our study of commercial groves, where $5 \%$ of the trees in one grove were on zygotic rootstock. There are few studies, particularly long-term ones, to show whether all zygotics are undesirable, and if so, what impact they would have on overall grove performance. One reason for eliminating zygotic rootstock plants was evident. Some of the commercial trees on zygotic seedlings that we identified appeared to be declining.

\section{Literature Cited}

Barrett, H.C. and D.J. Hutchison. 1978. Spontaneous tetraploidy in apomictic seedlings of Citrus. Econ. Bot. 32:27-45.

Cardy, B.J., C.W. Stuber, and M.M. Goodman. 1981. Techniques for starch gel electrophoresis of enzymes from maize (Zea mays L.). Inst. of Statistics Mimeo. Ser. 1317, North Carolina State Univ., Raleigh.

Castle, W.S., H.K. Wutscher, C.O. Youtsey, and R.R. Pelosi. 1988. Citrumelos as rootstock for Florida citrus. Proc. Fla. State Hort. Soc. 101:28-33.

Hutchison, D.J. 1974. Swingle citrumelo-A promising rootstock hybrid. Proc. Fla. State Hort. Soc. 87:89-91.

Khan, I.A. and M.L. Roose. 1988. Frequency and characteristics of nucellar and zygotic seedlings in three cultivars of trifoliate orange. J. Amer. Soc. Hort. Sci. 113:105-110.

Loukas, M. and C.A. Pontikis. 1979. Pollen isozyme polymorphism in types of Pistacia vera and related species as an aid in taxonomy. J. Hort. Sci. 54:95-102.

Moore, G.A. and W.S. Castle. 1988. Morphological and isozymic analysis of open-pollinated citrus rootstock populations. J. Hered. 79:59-63.

Roose, M.L. and S.N. Traugh. 1988. Identification and performance of citrus trees on nucellar and zygotic seedlings. J. Amer. Soc. Hort. Sci. 113:100-105.

Rouse, R.E. and H.K. Wutscher. 1985. Heavy soil and bud union creases with some clones of red grapefruit limit use of Swingle citrumelo rootstock. HortScience 20:259-261.

Sokal, R.R. and F.J. Rohlf. 1981. Biometry. 2nd ed. Freeman, San Francisco.

Torres, A.M., R.K. Soost, and V. Diedenhofen. 1978. Leaf isozymes as genetic markers in citrus. Amer. J. Bot. 65:869-881.

Torres, A.M., R.K. Soost, and T. Mau-Lastovicka. 1982. Citrus isozymes: Genetics and distinguishing nucellar from zygotic seedlings. J. Hered. 73:335-339.

Torres, A.M., T. Mau-Lastovicka, T.E. Williams, and R.K. Soost. 1985. Segregation distortion and linkage of Citrus and Poncirus isozyme genes. J. Hered. 76:289-294.

Vallejos, C.E. 1983. Enzyme activity staining, p. 469-516. In: S.D. Tanksley and T.J. Orton (eds.). Isozymes in plant genetics and breeding, Part A. Elsevier, Amsterdam.

Webber, H.J. 1932. Variations in citrus seedlings and their relation to rootstock selection. Hilgardia 7:1-79.

Xiang, C. and M.L. Roose. 1988. Frequency and characteristics of nucellar and zygotic seedlings in 12 Citrus rootstock. Scientia Hort. $37: 47-59$. 